\title{
Nutritional management of liver cirrhosis and its complications in hospitalized patients
}

\author{
Nida JAVAID', Ayesha Zafar IQBAL² and Maryam HAMEEDA ${ }^{3}$
}

Received: 28 September 2020

Accepted: 30 December 2020

\begin{abstract}
Background - Cirrhosis is a chronic and progressive liver disease that occurs from prolonged hepatocellular injury. Malnutrition causes complications in cirrhosis patients that worsen the condition to liver failure. Both are closely linked and increase the chances of morbidity and mortality. Regular nutritional screening and monitoring is prime concern for such patients including comprehensive dietary history, laboratory tests, and evaluation of muscle loss and strength capabilities to determine the degree of frailty. For efficient assessment of liver cirrhosis patients Subjective Global Assessment has been used worldwide. The nutritional objectives for such individuals should be to regain liver functions, to prevent complications associated, and to overcome nutritional deficiencies causing malnutrition. Methods - We conducted a literature review using PubMed, Google Scholar and Science Direct for this purpose, a total of 130 articles were reviewed out of which 80 (from the past 5 years) including originally published research, review articles and abstracts were also included. Exclusion criteria of the selected studies was year of publication, irrelevancy and animal studies based on the purpose of current study. The aim of this study was to check nutritional management in patients having complications of liver cirrhosis. Results - According to the guidelines, for the conservation of normal nutritional status of the malnourished patients', energy should be provided $35 \mathrm{kcal} / \mathrm{kg} /$ day while to prevent hypoalbuminemia and maintain the protein stores in the body, $1.5 \mathrm{~g} / \mathrm{kg} / \mathrm{day}$ protein has been recommended. Carbohydrates and fats for cirrhosis patients are recommended $50 \%$ to $60 \%$ and $10 \%$ to $20 \%$ of the total dietary intake respectively. Conclusion-Initial identification and prevention of malnutrition have the probability to lead to better health outcomes, prevention of complications of the disease, and improving quality of life.
\end{abstract}

Keywords - Cirrhosis; malnutrition; encephalopathy; nutritional support; quality of life.

\section{INTRODUCTION}

The liver is one of the major organs of the body that carries more than five hundred functions in the body. Metabolism of all macronutrients carbohydrates, fats and protein takes place in liver accordingly. Liver has been considered very significant in respect to nutrition. Moreover, it plays major roles in enzymatic functions of the body ${ }^{(1)}$. Liver cirrhosis is the progressive disorder of the liver in which normal hepatic cells are converted into scar tissues accompanied by loss of functioning ${ }^{(2)}$. Cirrhosis can be classified into two types. Compensated liver cirrhosis and decompensated liver cirrhosis. In the former type, liver tissues converted to diseased one with moderate loss of liver functioning while in decompensated liver cirrhosis, there will be increased damage to liver tissues with the progression of complications including hepatic encephalopathy, portal hypertension, ascites, edema, oesophageal varices and others ${ }^{(3,4)}$.

Portal hypertension in liver cirrhosis patients is related to other complications like ascites, intrahepatic vascular resistance, and esophageal varices. Portal hypertension can be defined as a pathological condition in which there is an increase in pressure gradient due to the obstruction of portal blood flow within the portal system ${ }^{(8)}$. It is the difference in the pressure between the portal vein and hepatic vein ${ }^{(9)}$.

From the past two decades' prevalence of liver cirrhosis have been increased approximately two folds. With the increased prevalence of chronic liver disease approximately two million deaths are reported worldwide due to liver cirrhosis ${ }^{(5)}$. Roughly 71 million patients with hepatitis $C$ and 257 million patients with hepatitis B virus had reported that are the leading causes of chronic liver disease and cirrhosis worldwide ${ }^{(6,7)}$.

There are many etiological factors of chronic liver disease and liver cirrhosis among them chronic hepatitis (B and C), steatohepatitis, alcoholic liver disease, non-alcoholic steatohepatitis (NASH), and non-alcoholic fatty liver disease (NAFLD) are common $^{(8-10)}$. Malnutrition is the most prominent issue in hospitalized chronic liver disease patients. Malnutrition occurred by multiple factors such as nausea, vomiting, early satiety, constipation, and liver cirrhosis complications ${ }^{(11)}$. Malnutrition at the early phase of chronic liver disease may increase the disease burden, early onset of complications, increase the length of hospital stay, morbidity, and mortality ${ }^{(12)}$.

\section{Nutrition assessment}

To combat malnutrition early nutrition screening within 24 to 48 hours of hospital stay should be needed. Malnutrition is closely linked with increases chances of morbidity and mortality in patients that may be explained as loss in mass and strength of skeletal muscles as well as reduced subcutaneous and visceral fats ${ }^{(13}$ it may be present in 5\% to $99 \%$ of the patients and also depends on the tools that are being used for assessment ${ }^{(14)}$. Complete nutrition

Declared conflict of interest of all authors: none

Disclosure of funding: no funding received

${ }^{1}$ University Institute of Diet and Nutritional Sciences, University of Lahore, Lahore, Pakistan. ${ }^{2}$ College of Allied Health Sciences, Akhtar Saeed Medical and Dental College, Lahore, Pakistan. ${ }^{3}$ Department of Food Science and Human Nutrition, University of Veterinary and Animal Sciences, Lahore, Pakistan.

Corresponding author: Nida Javaid. E-mail: nida.javaid23@gmail.com 
assessment comprises of anthropometric measurements, biochemical data, clinical assessment, and dietary evaluation. Assessment of all these parameters helps to provide adequate nutrition to the patient to prevent malnutrition ${ }^{(14,15)}$.

Anthropometric measurements in liver cirrhosis patients are a controversial issue due to edema and ascites in the patients. Body mass index that would be calculated by using dry weight of the patients can be a quick method for patients nutritional assessment, whereas, to get that complete picture of nutritional assessment the practitioner should be considering the methods and their limitations while assessing the liver cirrhosis patient ${ }^{(1,16,17)}$. Some methods are used to assess muscle functionality directly, but not the amount of muscle mass. These methods are useful because they can reflect, indirectly, body preservation (TABLE 1).

Sarcopenia (a most important criterion for the detection of malnutrition) is very common in patients with liver cirrhosis and it has been studied for many years. It is a progressive loss of function, strength, and mass of skeletal muscles ${ }^{(18)}$. Sarcopenia is characterized by loss of skeletal mass and strength related to the progression of the disease ${ }^{(19)}$. In chronic liver disease and cirrhosis sarcopenia is common as it reflects malnourishment in patients that further linked with altered cardiopulmonary performance, quality of life, increase morbidity, and mortality ${ }^{(20)}$.

Other nutrition assessment tools for liver cirrhosis patients include Chair Stand test, it is evaluated by counting the number of times a patient can fully stand up from the chair and sit down within 30 seconds without taking help from hands or any external object $^{(18)}$. A 6-minute walk test is another test that can be used to assess the functional capacity of hospitalized patients. It is simple, inexpensive, and required no training or special instructions before the test. It may be effected according to the patient's conditions and skeletomuscular morbidities ${ }^{(21)}$. Psoas muscle index is an easy method and not effect by the abdominal swelling. It can be used as a predictor of mortality in liver cirrhosis patients ${ }^{(22,23)}$. Accuracy of the test may be affected due to excess fluid in the body, BMI, and activity levels. Liver Frailty Index (LFI) is a test for assessment of physical function and related health outcomes in cirrhosis patients. It comprised three tests including handgrip strength, chair stand test, and balance ${ }^{(24)}$. LFI is non-expensive, safe, and easy to perform in conscious patients, its results may be affected if hepatic encephalopathy exists or due to patient's efforts ${ }^{(21)}$. Literature has supported the validity of the frailty index in cirrhosis patients for prediction of mortality ${ }^{(25)}$.

\section{Subjective global assessment}

For efficient assessment of liver cirrhosis patients Subjective Global Assessment (SGA) has been using worldwide. In SGA short term and long term data of the patients has been acquired by either questioning or physical assessment ${ }^{(26)}$. Parameters in SGA are weight change, dietary intake, gastrointestinal symptoms (nausea, vomiting, satiety, constipation, and others), functional capacity and ascites, and edema. It divides patients into three categories, wellnourished, moderately malnourished, and severely malnourished ${ }^{(14)}$.

There are other assessment tools to identify malnutrition in patients that include the Malnutrition Universal Screening Tool (MUST). In this tool malnutrition among patients can be detected by using weight loss, body mass index, and disease-related dysfunction.The results of MUST tool, categorized patients in low risk of malnutrition, medium and high risk of malnutrition based on the score assembeled subsequently. It can be used to be predictive validity for a length of hospital stay ${ }^{(27)}$. Mini Nutrition Assess-

TABLE.1 Anthropometric measurement in liver cirrhosis patients.

\begin{tabular}{|c|c|c|}
\hline Methods & Uses & Limitations \\
\hline $\begin{array}{l}\text { Body mass } \\
\text { index (BMI) }\end{array}$ & $\begin{array}{l}\text { Quick, non-invasive method } \\
\text { for nutrition assessment of } \\
\text { hospitalized patients. For liver } \\
\text { cirrhosis patients BMI can be } \\
\text { calculated by using dry weight. } \\
\text { It can be measured by using the } \\
\text { formula } \\
\text { BMI = weight in } \mathrm{kg} / \mathrm{Height} \text { in } \mathrm{m}^{2} \\
\text { BMI classified as } \\
\text { Underweight }\left(\mathrm{BMI}<18 \mathrm{~kg} / \mathrm{m}^{2}\right)\end{array}$ & $\begin{array}{l}\text { Reduce } \\
\text { reliability for } \\
\text { liver cirrhosis } \\
\text { patients due } \\
\text { to the presence } \\
\text { of ascites and } \\
\text { edema. }\end{array}$ \\
\hline
\end{tabular}

Normal (BMI $18.5-24.9 \mathrm{~kg} / \mathrm{m}^{2}$ )

Overweight (BMI $25-29.9 \mathrm{~kg} / \mathrm{m}^{2}$ )

Obese $\left(\mathrm{BMI}>30 \mathrm{~kg} / \mathrm{m}^{2}\right)$

It is measured by using a measuring tape from the

Mid

upper arm circumference (MUAC)

Mid arm muscle circumference (MAMC)

Triceps skin fold thickness (TSF)

\section{DEXA}

Bioelectrical Impedance analysis (BIA)

Hand grip strength acromion process of the scapula to the olecranon process in $\mathrm{cm}$. It predicts the muscle mass of the body. Its values are also valuable to calculate MAMC of the patients for a clear depiction of muscle mass of the body.

It is an easy non-invasive body measurement method for patients. It predicts about muscle mass of the body. MAMC values are not affected by fluid retention. It can be measured by using the formula MAMC $=($ MAC-TSF $\times 0.341)$

It is the body measurement method used to assess the fat mass. In liver cirrhosis patients for identification of sarcopenia TSF is a better method. TSF values are not affected by fluid status. It is measured by the help of TSF caliper in $\mathrm{mm}$.

It is a body measurement method that assesses lean soft tissues, bone mineral content, and fat mass.

It acts on the conductance of hydrated tissues, measures the total volume of body water and assesses the lean body mass through an equation

It is used to record the mean value after taking three measurements by the dominant arm gripping the dynamometer and the value is recorded in kilograms
Reliability of this tool is based on the observer experience Difficult to identify patients with severe malnutrition.

Reliability of this tool is based on the observer experience.

The reliability of this tool is based on observer experience.

Difficult to

identify patients with severe malnutrition Cannot be estimated correctly in people having ascites or edema.

DEXA

miscalculates the prevalence of sarcopenia in patients with fluid overload.

$$
\text { It is }
$$

controversial to use in decompensated liver cirrhosis.

$$
\text { It is an }
$$
independent factor for mortality but it weekly correlates with muscle mass. 
ment tool (MNA) is used for elder patients and includes a dietary questionnaire, predict social and mental functioning to predict malnutrition $^{(28)}$. In MNA, patients were categorized as with normal nutritional status, at risk of malnourishment and malnourished based on the score calculation.

\section{Biomarkers}

Biomarkers that represent serum albumin are very important in assessing the nutritional status of the patient as the synthesis and breakdown of albumin decreases in liver cirrhosis as compared to a person having a normal liver function. Other biomarkers include red blood cell count, liver function tests, cholinesterase, albumin, rapid turnover proteins, vitamins (A, D, E, K, B6, B12, and folate) minerals, adipocytokines and creatinine height index in the urine. Serum albumin concentration can be affected by many factors such as the type and amount of food taken, digestion, and absorption from the intestine. It is the main secretion protein and synthesis occurs in the liver but its concentration decreases in patients with liver cirrhosis as compared to the one having normal liver functions ${ }^{(29)}$.

To check the short term status of nutrition in liver cirrhosis patients' rapid turnover proteins that include pre-albumin, retinolbinding protein, and transferrin are also used as biomarkers ${ }^{(17)}$. Adipocytokines are also important biomarkers for nutritional status. Leptin, adiponectin, and resistin are important peptide hormones. Plasma adiponectin comes in three forms; low molecular weight, medium, and high molecular weight. And in patients with liver cirrhosis, high molecular weight form is increased and is also related to the severity of liver damage in such patients. Vitamins (both fat and water-soluble), as well as trace minerals such as copper, zinc, iron, selenium and manganese, should also need to be considered while having a nutrition assessment of the patient ${ }^{(30)}$.

\section{Dietary intake}

The composition of food and drinks with their meal schedule should be asked in this category of nutrition assessment. Periods of fasting should also be a notable point because it may cause harm in cirrhotic patients. Twenty-four-hour dietary recalls, food frequency questionnaires, and calorie counts are the tools that should be used to check if the patients are meeting their required caloric and nutritional needs $\mathrm{s}^{(31)}$. Factors that hinder oral intake should also be noticed and addressed ${ }^{(13)}$. But it may hinder the correct results because it depends on the patients' memory to recall the food eaten ${ }^{(14)}$.

\section{Nutritional management}

For hospitalized liver cirrhosis patients, after complete assessment, medical nutrition therapy should be applied. The provision of adequate calories and protein should be ensured to prevent malnutrition. To provide adequate nutrients balanced oral diet is highly recommended. In liver cirrhosis, the patient's ratio of aromatic amino acid and branched-chain amino acids is disturbed due to hyper metabolism, altered liver function, and decrease dietary intake $^{(32)}$. Oral supplementation in patients with malnutrition or borderline nutritional status is a better option to avoid further deterioration. General recommendations such as small and frequent meals, snacks enriched in branched-chain amino acids have been supported by many studies for liver cirrhosis patients. Patients that are unable to take essentials through oral diet should be transferred to enteral nutrition. In patients with contraindication of enteral nutrition after assessing their conditions and time of regime practitioner switch it to parenteral nutrition support.
Nutritional support has been prioritized for liver cirrhosis patients to prevent and manage malnutrition as evidenced by literature. The priority of nutrition restoration in cirrhosis patients is the provision of adequate calories and protein. The next priorities for hospitalized patients are the management of meal frequency and quality of protein $^{(33)}$. For hospitalized patient's hyperglycaemia has been reported as a common complication in many studies. That is linked with the hyper metabolic state and altered functioning of the liver. For both peripheral parenteral nutrition and total parental nutrition, hyperglycaemia should be avoided in the patients by giving glucose $2-3 \mathrm{~g} / \mathrm{kg} /$ day or less than or equal to $1 \mathrm{~g} / \mathrm{kg} /$ day. Other than this in patients with ascites and edema fluid overload should be avoided by providing high concentration formulas ${ }^{(34)}$. According to ESPEN (European Society for Clinical Nutrition and Metabolism) guidelines of nutritional management in liver cirrhosis patients, for the conservation of normal nutritional status of the malnourished patient's, energy should be provided $35 \mathrm{kcal} / \mathrm{kg} /$ day while to prevent hypoalbuminemia and maintain the protein stores in the body, $1.5 \mathrm{~g} / \mathrm{kg} /$ day protein has been recommended (TABLE $2)^{(8,35,36)}$. Carbohydrates and fats for liver cirrhosis patients are recommended $50 \%$ to $60 \%$ and $10 \%$ to $20 \%$ of the total dietary intake respectively ${ }^{(37-39)}$.

TABLE 2. Nutritional recommendations in liver cirrhosis.

\begin{tabular}{lcc}
\hline $\begin{array}{l}\text { Categories } \\
\text { (Nutritional status) }\end{array}$ & \multicolumn{2}{c}{ Nutritional recommendations } \\
\hline \multirow{3}{*}{ Malnourished } & Calories & $30-40 \mathrm{kcal} / \mathrm{kg}$ body weight $/ \mathrm{day}$ \\
& Protein & $1.2-1.5 \mathrm{~g} / \mathrm{kg}$ body weight $/ \mathrm{day}$ \\
& Lipids & $10-20 \%$ of daily requirements \\
& Calories & $35 \mathrm{kcal} / \mathrm{kg}$ body weight $/ \mathrm{day}$ \\
Normally nourished & Protein & $1.5 \mathrm{~g} / \mathrm{kg}$ body weight $/ \mathrm{day}$ \\
& Lipids & $10-20 \%$ of daily requirements \\
& Calories & $20-25 \mathrm{kcal} / \mathrm{kg}$ body weight $/$ day \\
Overweight and obese & Protein & $>1.5 \mathrm{~g} / \mathrm{kg}$ body weight $/$ day \\
& Lipids & $10-20 \%$ of daily requirements \\
\hline
\end{tabular}

Recent studies have reported that for hospitalized liver cirrhotic patient's nutrition care process could be better attained by early nutrition screening with the help of a multidisciplinary team, continuous monitoring at certain intervals, and follow up. This kind of approach will help the patients to reduce disease-related malnutrition and complications ${ }^{(40)}$. Nutrition therapy in cirrhotic patients and chronic alcoholic hepatitis patients has been proved to be beneficial to reduce complications, morbidity, and mortality ${ }^{(41)}$.

Micronutrient deficiency in liver cirrhosis patients is also stated that is possibly due to inadequate oral intake, restricted diet, altered taste, gastrointestinal problems, and others. A systematic review had reported the effect of severe vitamin D deficiency on mortality rates of hospitalized liver cirrhosis patients. Supplementation within the upper limit ranges can be supplemented to the patients, Moreover, there is a need for conduction of clinical trials to identify the efficiency of vitamin D supplementation on clinical outcomes of the patients ${ }^{(42)}$. A study was performed to assess trace minerals (copper, selenium, zinc, and magnesium) levels in liver cirrhosis patients and associate them with the severity of the disease. The result showed a significant decrease in the trace minerals except for copper. A significant correlation was found between trace minerals status and severity of disease that was further linked with liver dysfunction ${ }^{(43)}$. 
Inadequate oral intake in liver cirrhosis patients is the key factor participating in malnutrition. Diseased patients are unable to take adequate calories and protein resulting in deteriorated nutritional status. Various studies stated different methods to increase oral intake of hospitalized liver cirrhosis patients that includes smaller meals with increased frequency, improves sensory characteristics of the meal, mealtime without any interruption, and nutrition education $^{(37,44,45)}$. To prevent and reverse the degree of malnutrition in patients, improvement of dietary intake is a crucial factor. A study was conducted to improve the intake of patients enriched with BCAA. For this purpose, late evening snacks enriched with BCAA was introduced to liver cirrhosis patients. Results showed that the Fischer ratio (BCAA: AAA) was significantly increased in patients with late evening snacks as compared to control ${ }^{(46)}$. Fischer ratio is defined as the ratio of branched chain amino acids to aromatic amino acids and is important for assessing liver metabolism, hepatic functional reserve and liver dysfunction severity. The study suggested that providing patients with late evening snacks helps in the improvement of total dietary intake as well as the Fischer ratio that prevents patients from further complications ${ }^{(47)}$.

A randomized control trial has been conducted in liver cirrhosis patients to investigate the effect of high protein, high fiber diet supplemented with branched-chain amino acids for 6 months. The study showed an increase in muscle mass and a decrease in fat mass in the trail group while the levels of ammonia and glucose in serum did not elevate. Hence, supplementation of BCAA with protein and fiber is worth considering intervention among cirrhotic patients ${ }^{(48)}$. Another clinical trial was conducted in post-operative liver cirrhosis patients to assess the efficacy of parenteral fatty acids in the recovery of patients. Results showed that patients receiving 10\%n-3 fatty acids for 5 days (post-operation) had reduced morbidity and mortality as compared to other patients as well as there was decrease length of hospital stay and infections among the patients ${ }^{(49)}$.

Hospitalized liver cirrhosis patients who are unable to take adequate nutrition related to other complications should be shifted towards enteral nutrition support. Routes can be varying in patients according to the patient's conditions that would be either nasogastric feeding, nasojejunal feeding, or percutaneous endoscopic gastrostomy feeding protocols ${ }^{(50)}$. Patients on enteral nutrition should be monitored appropriately to avoid complications.

In critically ill patients, enteral nutrition should be initiated with 10-20 mL per hour with critical monitoring of gastrointestinal symptoms. The energy and protein supply of patients will be planned with a lower level to prevent feeding intolerance ${ }^{(51)}$. In liver cirrhosis key objective of nutritional management is the prevention of malnutrition and maintenance of nutritional status in patients. For this purpose, adequate energy and protein intake should be prioritized. Energy expenditure can be calculated by using formulas or directly according to ESPEN (European Society for Clinical Nutrition and Metabolism) guidelines ${ }^{(32)}$. Sources of protein should be introduced precisely to the patients according to the condition of patients. Protein sources can vary from animal sources to plant sources by taking BCAA to AAA ratio under consideration to prevent further complications ${ }^{(52)}$.

\section{Complications of liver cirrhosis and nutrition management}

One of the most common complications reported in decompensated liver cirrhosis patients is ascites. Ascites is well-defined as less than or equal to $200 \mathrm{~mL}$ fluid accumulation in the abdominal cavity as a result of any clinical manifestation. Pathophysiology of ascites in liver cirrhosis patients is portal hypertension and hypoalbuminemia for most of the cases. Usually, ascites is further classified into three grades based on the signs and symptoms and volume of fluid accumulated in the peritoneal cavity ${ }^{(53)}$. Some of the studies support the nutritional management of ascites as sodium and total fluid intake restriction for the shorter duration of time ${ }^{(54)}$, furthermore, providing adequate calories and protein to the patient prevents them, from hypoalbuminemia that will help the patients against ascites ${ }^{(55)}$. According to the European association for the study of liver, limited data was available on the sodium levels recommendation in ascites. However, the study supported sodium restriction (1.8-2.0 grams/day) would be helpful in patients with edema and ascites ${ }^{(56,57)}$.

Hepatic encephalopathy is another severe liver cirrhosis complication that is defined as brain dysfunction associated with liver insufficiency and portal hypertension leading to end-stage liver disease, morbidity, and mortality in patients ${ }^{(58)}$. Hepatic encephalopathy is categorized into four stages that depend upon the signs and symptoms of the patients ${ }^{(59)}$. Grade 1 patients are characterized by sleep disorder and altered attention, grade 2 includes patients with complaints of disorientation, personality disorders, and lethargy. Grade 3 is described with confusion, altered speech, and disorientation that is followed by comma categorized as stage 4 of hepatic encephalopathy ${ }^{(60)}$. Nutritional management in this stage is very crucial. Although protein restriction is controversial in hepatic encephalopathy. A systemic study reported 16 randomized trials on hepatic encephalopathy patients concluded that the provision of branched-chain amino acid rich sources has beneficial effects on patients. In advanced liver cirrhosis, the patient's level of branched-chain amino acids (leucine, isoleucine, and valine) in serum decreased resulting in hepatic encephalopathy. Branchedchain amino acids facilitate the synthesis of glutamate by providing nitrogen to alpha-ketoglutarate ${ }^{(61)}$. Glutamate is a substrate in brain and muscle cells for ammonia detoxification into glutamine. In advanced liver disease patient ratio of aromatic amino acids (tyrosine, tryptophan, and phenylalanine) and branched-chain amino acids decreases commonly termed as Fischer ratio. A decrease in the Fischer ratio characterizes progression in liver disease resulting in hepatic encephalopathy ${ }^{(62)}$. Supplementation of BCAA helps in liver cirrhosis to prevent complications and improve survival rates $^{(63)}$. Nutritional recommendations for hepatic encephalopathy are further categorized based on severity. For low-grade hepatic encephalopathy patients (grade 1,2) 25-35 kcal/day calories and $1-1.5 \mathrm{~g} / \mathrm{kg} /$ day while for severe encephalopathy patients (garde 3,4) $25-35 \mathrm{kcal} /$ day calories and $>1 \mathrm{~g} / \mathrm{kg} /$ day protein is recommended. Protein sources in such types of patients should be shifted towards plant sources with BCAA rich solutions ${ }^{(64,65)}$.

A longitudinal study was planned in liver cirrhosis patients to evaluate the effect of branched-chain amino acids in glucose metabolism, skeletal muscle, and survival of patients ${ }^{(66)}$. Results revealed that after dietary branched-chain amino acids for 48 weeks there was a significant decrease in intramuscular adipose tissue while skeletal muscle mass increases that improved the survival of liver cirrhosis patients ${ }^{(67)}$. Another retrospective cohort study was done recently to evidence the beneficial effects of long term supplementation of BCAA in liver disease. In a group where patients take supplementation for approximately 6 months, there was a significant improvement in the MELD (model for end stage liver disease) score as compared to the control group. A MELD score 
is basically a number that ranges from 6-40 and it tells about the degree of sickness and the need of the transplant, higher score denotes higher need of liver transplant. Moreover, there was a significant difference in serum albumin, bilirubin and CP score between both groups ${ }^{(68)}$. Systematic reviews supported beneficial effects of BCAA supplementation especially improving muscle strengths, survival rates, edema, and ascites in hepatic encephalopathy patients ${ }^{(69)}$. Another study was reported to highlight the importance of branched-chain amino acids supplementation in liver cirrhosis patients for improving muscle strength and volume ${ }^{(70,71)}$.

Another major complication in decompensated liver cirrhosis patients is oesophageal varices. Oesophageal varices is defined as enlarged veins of esophagus resulting due to obstructed blood flow from portal vein. In case of severe complications (as stated above) and inadequate oral intake, first priority of optimizing nutrition is oral supplementation that will progress towards nutritional support based on patient's condition ${ }^{(1,53,54)}$.

Portal hypertension is another complication in liver cirrhosis patients further associated with ascites, intrahepatic vascular resistance, hepatic encephalopathy and oesophageal varices. Literauture suggested that portal hypertension can be efficiently reduced by various approaches to prevent disease related complications and malnutrition in advanced liver cirrhosis patients ${ }^{(72)}$.

There are multiple contributing factors for malnutrition in advanced liver disease patients. Most important is an inadequate oral intake that is associated with dysgeusia, anorexia, early satiety, restricted diet, and NPO for a certain duration of time as criteria for testing. Hyper metabolism and malabsorption in liver cirrhosis patients are also a causative factor in malnutrition that is due to ascites, increased protein metabolism, impaired glycogen metabolism, bacterial overgrowth, and impaired bile secretion ${ }^{(73,74)}$. Cirrhotic patients with the above mentioned complications have an increased probability of malnutrition ${ }^{(75)}$. Malnourishment in such patients causes deterioration of not only anthropometric measure- ments but also affects biochemical profile and dietary intake. In liver cirrhosis, malnutrition is linked with decreased liver functioning, handgrip strength, and quality of life $\mathrm{e}^{(76-78)}$.

\section{CONCLUSION}

In summary, malnutrition is exceptionally prevalent among cirrhosis patients. Regardless of cause and severity, it is important to screen all patients to identify the malnutrition in such patients. Although several assessment tools are available for scoring the severity of complications a standardized simple and accurate method for evaluating malnutrition remains a challenge in endstage liver disease patients. Precise and accurate assessment of nutritional status in cirrhotic patients is the top priority so that proper nutrition intervention can be planned and implemented to prevent complications of the disease. Intake of quality protein and adequate supplementation can overcome deficiencies and complications associated with end-stage liver failure. Guideline for a nutritional recommendations and dietary plan must be referred with ESPEN (European Society for Clinical Nutrition and Metabolism) and EASL (European Association for the Study of the Liver) for chronic liver disease and cirrhosis patients.

\section{Authors' contribution}

Javaid $\mathrm{N}$ compiled the initial literature review, conceptualize study design and write up the initial draft of the paper. Iqbal AZ complete the literature research as well as review and edit the document at each stage. Hameeda $\mathrm{M}$ helped with the write up of initial draft and revision of manuscript.

\section{Orcid}

Nida Javaid: 0000-0002-6734-134X.

Ayesha Zafar: 0000-0003-4175-0062.

Maryam Hameeda: 0000-0002-1298-5914.

Javaid N, Iqbal AZ, Hameeda M. Manejo nutricional da cirrose hepática e suas complicações em pacientes hospitalizados. Arq Gastroenterol. 2021;58(2):246-52.

RESUMO - Contexto - A cirrose hepática é uma doença crônica e progressiva que ocorre por lesão hepatocelular prolongada. A desnutrição causa complicações em pacientes com cirrose que pioram a condição para insuficiência hepática. A cirrose e a desnutrição estão intimamente ligadas e aumentam as chances de morbidade e mortalidade. O rastreamento e monitoramento nutricional regulares são as principais preocupações para esses pacientes, incluindo histórico alimentar abrangente, testes laboratoriais e avaliação de capacidades de perda muscular e força para determinar o grau de fragilidade. Para uma avaliação eficiente de pacientes com cirrose hepática, a Avaliação Global Subjetiva tem sido usada em todo o mundo. Os objetivos nutricionais desses indivíduos devem ser recuperar as funções hepáticas, prevenir complicações associadas e superar deficiências nutricionais que causam desnutrição. Métodos - Realizada uma revisão de literatura usando PubMed, Google Scholar e Science Direct para este fim, e um total de 130 artigos foram revisados dos quais 80 (dos últimos 5 anos), incluindo pesquisas publicadas originalmente. Artigos de revisão e resumos também foram incluídos. Os critérios de exclusão dos estudos selecionados foram ano de publicação, irrelevância e estudos em animais com base na finalidade do estudo atual. O objetivo deste estudo foi verificar o manejo nutricional em pacientes com complicações da cirrose hepática. Resultados - De acordo com as diretrizes, para a conservação do estado nutricional normal dos pacientes desnutridos, a energia deve ser fornecida $35 \mathrm{kcal} / \mathrm{kg} /$ dia, enquanto para prevenir hipoalbuminemia e manter os estoques de proteínas no corpo, $1,5 \mathrm{~g} / \mathrm{kg} / \mathrm{dia}$ de proteína foi recomendada. Carboidratos e gorduras para pacientes com cirrose são recomendados de $50 \%$ a $60 \%$ e $10 \%$ a $20 \%$ da ingestão alimentar total, respectivamente. Conclusão - A identificação inicial e a prevenção da desnutrição têm a probabilidade de levar a melhores desfechos de saúde, prevenção de complicações da doença e melhoria da qualidade de vida.

Palavras-chaves - Cirrose; desnutrição; encefalopatia; suporte nutricional; qualidade de vida. 


\section{REFERENCES}

1. Shergill R, Syed W, Rizvi SA, Singh I. Nutritional support in chronic liver disease and cirrhotics. World J Hepatol. 2018;10:685-94.

2. Haj M, Rockey DC. Predictors of clinical outcomes in cirrhosis patients. Curr Opin Gastroen. 2018;34:266-71.

3. Mansour D, McPherson S. Management of decompensated cirrhosis. Clin. Med. 2018;18(Suppl 2):s60-s5.

4. Blasco-Perrin H, Bureau C. [Management of patients with decompensated liver cirrhosis]. Rev Prat. 2017;67:735-9.

5. Ganne-Carrié N. [Epidemiology of liver cirrhosis]. Rev Prat. 2017;67:726-30.

6. Moon AM, Singal AG, Tapper EB. Contemporary Epidemiology of Chronic Liver Disease and Cirrhosis. Clin Gastroenterol Hepatol. 2020 Nov;18:2650-66.

7. Global prevalence, treatment, and prevention of hepatitis B virus infection in 2016: a modelling study. Lancet Gastroenterol. 2018;3:383-403.

8. Stirnimann J, Stirnimann G. Nutritional Challenges in Patients with Advanced Liver Cirrhosis. J Clin Med. 2019 Nov 9;8:1926.

9. Castera L, Friedrich-Rust M, Loomba R. Noninvasive Assessment of Liver Disease in Patients With Nonalcoholic Fatty Liver Disease. Gastroenterol. 2019; 156:1264-81.

10. Romanelli RG, Stasi C. Recent Advancements in Diagnosis and Therapy of Liver Cirrhosis. Curr. 2016;17:1804-17.

11. Dasarathy $\mathrm{S}$. Cause and management of muscle wasting in chronic liver disease. Curr Opin Gastroenterol. 2016;32:159-65

12. Parkash O, Jafri W, Munir SM, Iqbal R. Assessment of malnutrition in patients with liver cirrhosis using protein calorie malnutrition (PCM) score verses bio-electrical impedance analysis (BIA). BMC Res Notes. 2018;11:545.

13. Calmet F, Martin P, Pearlman M. Nutrition in patients with cirrhosis. Gastroenterol Hepatol. 2019;15:248

14. Tandon P, Raman M, Mourtzakis M, Merli M. A practical approach to nutritional screening and assessment in cirrhosis. Hepatol. 2017;65:1044-57.

15. Molfino A, Johnson S, Medici V. The Challenges of Nutritional Assessment in Cirrhosis. Curr Nutr Rep. 2017;6:274-80.

16. EASL Clinical Practice Guidelines on nutrition in chronic liver disease. J Hepatol. 2019;70:172-93.

17. Anand AC. Nutrition and Muscle in Cirrhosis. J Clinic Exp Hepatol. 2017;7:340 57.

18. Buchard B, Boirie Y, Cassagnes L, Lamblin G, Coilly A, Abergel A. Assessment of Malnutrition, Sarcopenia and Frailty in Patients with Cirrhosis: Which Tools Should We Use in Clinical Practice? Nutrients. 2020;12:186.

19. Kim G, Kang SH. Prognostic value of sarcopenia in patients with liver cirrhosis: A systematic review and meta-analysis. PLoS One. 2017;12:e186990.

20. Hsu CS, Kao JH. Sarcopenia and chronic liver diseases. Expert Rev Gastroen. 2018;12:1229-44.

21. Sinclair M. Controversies in Diagnosing Sarcopenia in Cirrhosis-Moving from Research to Clinical Practice. Nutrients. 2019;11:2454.

22. Ebadi M, Wang CW, Lai JC, Dasarathy S, Kappus MR, Dunn MA, et al. Poor performance of psoas muscle index for identification of patients with higher waitlist mortality risk in cirrhosis. J Cachexia Sarcopeni. 2018;9:1053-62.

23. Murea M, Lenchik L, Register TC, Russell GB, Xu J, Smith SC, et al. Psoas and paraspinous muscle index as a predictor of mortality in African American men with type 2 diabetes mellitus. J diabetes complications. 2018;32:558-64.

24. Wang CW, Lebsack A, Chau S, Lai JC. The Range and Reproducibility of the Liver Frailty Index. Liver Transpl. 2019;25:841-7.

25. Lai JC, Covinsky KE, Dodge JL, Boscardin WJ, Segev DL, Roberts JP, et al Development of a novel frailty index to predict mortality in patients with endstage liver disease. Hepatol. 2017;66:564-74

26. Ciocîrlan M, Cazan AR, Barbu M, Mănuc M, Diculescu M, Ciocîrlan M Subjective Global Assessment and Handgrip Strength as Predictive Factors in Patients with Liver Cirrhosis. Gastroenterol Res Pract. 2017;2017:8348390.

27. Rabito EI, Marcadenti A, da Silva Fink J, Figueira L, Silva FM. Nutritional Risk Screening 2002, Short Nutritional Assessment Questionnaire, Malnutrition Screening Tool, and Malnutrition Universal Screening Tool Are Good Predictors of Nutrition Risk in an Emergency Service. J Parenter Enter Nutr. 2017; 32:526-32.

28. Donini LM, Poggiogalle E, Molfino A, Rosano A, Lenzi A, Rossi Fanelli F, et al. Mini-Nutritional Assessment, Malnutrition Universal Screening Tool, and Nutrition Risk Screening Tool for the Nutritional Evaluation of Older Nursing Home Residents. J Am Med Dir Assoc. 2016;17:959.e11-8.

29. Spinella R, Sawhney R, Jalan R. Albumin in chronic liver disease: structure, functions and therapeutic implications. Hepatol Int. 2016;10:124-32.

30. Suzuki K, Endo R, Kato A. Nutritional Status in Liver Cirrhosis. Liver Cirrhosis-Update and Current Challenges. 2017:139-54. DOI.org/10.5772/intechopen. 68828
31. Palmese F, Bolondi I, Giannone FA, Zaccherini G. The Analysis of Food Intake in Patients with Cirrhosis Waiting for Liver Transplantation: A Neglected Step in the Nutritional Assessment. Nutrients. 2019;11:2462.

32. Ruiz-Margáin A, Méndez-Guerrero O, Román-Calleja BM, González-Rodríguez S, Fernández-Del-Rivero G, Rodríguez-Córdova PA, et al. Dietary management and supplementation with branched-chain amino acids in cirrhosis of the liver. Rev Gastroenterol Mex. 2018;83:424-33.

33. Moss O. nutrition Priorities: Diet recommendations in liver Cirrhosis. Clin Liver Dis. 2019;14:146.

34. Lee TH. [Nutritional Assessment and Management for Patients with Chronic Liver Disease]. Korean J Gastroenterol. 2018;71:185-91.

35. Plauth M, Bernal W, Dasarathy S, Merli M, Plank LD, Schütz T, et al. ESPEN guideline on clinical nutrition in liver disease. Clin Nutr. 2019;38:485-521.

36. Schiavo L, Busetto L, Cesaretti M, Zelber-Sagi S, Deutsch L, Iannelli A. Nutritional issues in patients with obesity and cirrhosis. World J Gastroenterol. 2018;24:3330-46

37. Perumpail BJ, Li AA, Cholankeril G, Kumari R, Ahmed A. Optimizing the Nutritional Support of Adult Patients in the Setting of Cirrhosis. Nutrients. 2017;9:1114.

38. Hammad A, Kaido T, Aliyev V, Mandato C, Uemoto S. Nutritional therapy in liver transplantation. Nutrients. 2017;9:1126.

39. Anastacio LR, Correia MITD. Nutrition therapy: Integral part of liver transplant care. World J Gastroenterol. 2016;22:1513.

40. Nartey YA, Asem M, Agyei-Nkansah A, Awuku YA, Setorglo J, Duah A, et al. Nutritional management of cirrhosis patients: A qualitative study exploring perceptions of patients and health workers in Ghana. Clin Nutr. ESPEN. 2019;34:18-22

41. Fialla AD, Israelsen M, Hamberg O, Krag A, Gluud LL. Nutritional therapy in cirrhosis or alcoholic hepatitis: a systematic review and meta-analysis. Liver Int. 2015;35:2072-8

42. Yang F, Ren H, Gao Y, Zhu Y, Huang W. The value of severe vitamin D deficiency in predicting the mortality risk of patients with liver cirrhosis: A meta-analysis. Clin Res Hepatol Gastroenterol. 2019;43:722-9.

43. Nangliya V, Sharma A, Yadav D, Sunder S, Nijhawan S, Mishra S. Study of trace elements in liver cirrhosis patients and their role in prognosis of disease. Biol. Trace Elem. Res. 2015;165:35-40.

44. Chao A, Waitzberg D, de Jesus RP, Bueno AA, Kha V, Allen K, et al. Malnutrition and nutritional support in alcoholic liver Disease: A review. Curr Gastroenterol Rep. 2016;18:65.

45. Alavinejad P, Hajiani E, Danyaee B, Morvaridi M. Efficacy of education, continuous monitoring and nutritional care on quality of life of cirrhotic patients and reducing of liver cirrhosis complications. J Infect Endem Dis. 2019;9:167-75.

46. Maki H, Yamanaka-Okumura H, Katayama T, Ozawa Y, Hosoda A, Kurata N, et al. Late evening snacks with branched-chain amino acids improve the Fischer ratio with patients liver cirrhosis at fasting in the next morning. Clin Nutr ESPEN. 2019;30:138-44

47. Theodoridis X, Grammatikopoulou MG, Petalidou A, Kontonika SM, Potamianos SP, Bogdanos DP. A Systematic Review of Medical Nutrition Therapy Guidelines for Liver Cirrhosis: Do We Agree? Nutr Clin Pract. 2020;35:98-107.

48. Ruiz-Margáin A, Macías-Rodríguez R, Ríos-Torres S, Román-Calleja B, Méndez-Guerrero O, Rodríguez-Córdova P, et al. Effect of a high-protein, high-fiber diet plus supplementation with branched-chain amino acids on the nutritional status of patients with cirrhosis. Rev Gastroenterol Mex. 2018;83:9-15.

49. Zhang B, Wei G, Li R, Wang Y, Yu J, Wang R, et al. n-3 fatty acid-based parenteral nutrition improves postoperative recovery for cirrhotic patients with liver cancer: A randomized controlled clinical trial. Clin Nutr. 2017:36:1239-44.

50. McClave SA, DiBaise JK, Mullin GE, Martindale RG. ACG Clinical Guideline: Nutrition Therapy in the Adult Hospitalized Patient. Am. J Gastroenterol. 2016;111:315-34

51. Blaser AR, Starkopf J, Alhazzani W, Berger MM, Casaer MP, Deane AM, et al. Early enteral nutrition in critically ill patients: ESICM clinical practice guidelines. Intensive Car Med. 2017;43:380-98

52. Grancini V, Resi V, Palmieri E, Pugliese G, Orsi E. Management of diabetes mellitus in patients undergoing liver transplantation. Pharmacol Res. 2019;141:556-73.

53. Smith A, Baumgartner K, Bositis C. Cirrhosis: Diagnosis and Management. Am Fam Physician. Am Fam Physician. 2019;100:759-70.

54. DiNorcia J, Colquhoun SD. Perioperative Management and Nutritional Support in Patients With Liver and Biliary Tract Disease. Shackelford's Surgery of the Alimentary Tract, 2 Volume Set: Elsevier; 2019. p. 1410-9.

55. Xu X, Duan Z, Ding H, Li W, Jia J, Wei L, et al. Chinese guidelines on the management of ascites and its related complications in cirrhosis. Hepatol Int. 2019;13:1-21. 
56. Yao CK, Fung J, Chu NHS, Tan VPY. Dietary Interventions in Liver Cirrhosis J Clin Gastroenterol. 2018;52:663-73.

57. EASL Clinical Practice Guidelines for the management of patients with decompensated cirrhosis. J Hepatol. 2018;69:406-60.

58. Gluud LL, Dam G, Les I, Córdoba J, Marchesini G, Borre M, et al. Branchedchain amino acids for people with hepatic encephalopathy. Cochrane Database Syst Rev. 2015:Cd001939.

59. Tan L, Meng Y, Zeng T, Wang Q, Long T, Wu S, et al. Clinical diagnostic significance of prealbumin, cholinesterase and retinol binding protein in liver cirrhosis combined with encephalopathy. Br. J. Biomed Sci. 2019;76:24-8

60. Butterworth RF. Hepatic encephalopathy. Liver. 2020:615-29.

61. Holeček M. Branched-chain amino acids in health and disease: metabolism, alterations in blood plasma, and as supplements. Nutr Metab. 2018;15:33.

62. Tajiri K, Shimizu Y. Branched-chain amino acids in liver diseases. Transl Gastroenterol Hepatol. 2018;3:47.

63. Holeček M. Branched-chain amino acid supplementation in treatment of liver cirrhosis: Updated views on how to attenuate their harmful effects on cataplerosis and ammonia formation. Nutrition. 2017;41:80-5.

64. Milke García MdP. Nutritional support in the treatment of chronic hepatic encephalopathy. Ann Hepatol. 2016;10(S2):45-9.

65. Campollo O, Sprengers D, Dam G, Vilstrup H, McIntyre N. Protein tolerance to standard and high protein meals in patients with liver cirrhosis. World J Hepatol. 2017;9:667.

66. Tsien C, Davuluri G, Singh D, Allawy A, Ten Have GA, Thapaliya S, et al Metabolic and molecular responses to leucine-enriched branched chain amino acid supplementation in the skeletal muscle of alcoholic cirrhosis. Hepatol. 2015;61:2018-29.

67. Kitajima Y, Takahashi H, Akiyama T, Murayama K, Iwane S, Kuwashiro T, et al. Supplementation with branched-chain amino acids ameliorates hypoalbuminemia, prevents sarcopenia, and reduces fat accumulation in the skeletal muscles of patients with liver cirrhosis. J Gastroenterol. 2018;53:427-37.
68. Park JG, Tak WY, Park SY, Kweon YO, Jang SY, Lee YR, et al. Effects of branched-chain amino acids (BCAAs) on the progression of advanced liver disease: a Korean nationwide, multicenter, retrospective, observational, cohort study. Med. 2017;96(24)

69. Ooi P, Gilmour S, Yap J, Mager D. Effects of branched chain amino acid supplementation on patient care outcomes in adults and children with liver cirrhosis: A systematic review. Clin Nutr ESPEN. 2018;28:41-51.

70. Hiraoka A, Michitaka K, Kiguchi D, Izumoto H, Ueki H, Kaneto M, et al Efficacy of branched-chain amino acid supplementation and walking exercise for preventing sarcopenia in patients with liver cirrhosis. Eur J Gastroen Hep. 2017;29:1416-23.

71. Vidot H, Cvejic E, Finegan LJ, Shores EA, Bowen DG, Strasser SI, et al. Supplementation with synbiotics and/or branched chain amino acids in hepatic encephalopathy: A pilot randomised placebo-controlled clinical study. Nutrients. 2019;11:1810.

72. Sauerbruch T, Schierwagen R, Trebicka J. Managing portal hypertension in patients with liver cirrhosis. Res. 2018;7:F1000.

73. Kennett AR, Olson JC. Nutrition Management in the Critically Ill Patient with Cirrhosis. Curr Hepatol Rep. 2020:1-10. DOI.org/10.1007/s1 1901-020-00506-0

74. Wang X, Wu B. Critical issues in the diagnosis and treatment of liver cirrhosis. Gastroenterol Rep (Oxf). 2019;7:227-30.

75. Hammad A, Kaido T, Uemoto S. Perioperative nutritional therapy in liver transplantation. Surg Today. 2015;45:271-83.

76. García-Rodríguez MT, Pértega-Díaz S, López-Calviño B, Piñón-Villar MDC, Otero-Ferreiro A, Suárez-López F, et al. Nomogram and Validity of a Model for Predicting Malnutrition in Patients on Liver Transplant Lists. Dig Dis Sci. 2018;63:1952-61.

77. Huynh DK, Selvanderan SP, Harley HA, Holloway RH, Nguyen NQ. Nutritional care in hospitalized patients with chronic liver disease. World J Gastroenterol. 2015;21:12835-42.

78. Mandato C, Di Nuzzi A, Vajro P. Nutrition and liver disease. Multidisciplinary Digital Publishing Institute; 2018. 